\title{
Comparison of Air and Water Quenching of HDS Slugs
}

by

J. A. Burk

E. I. du Pont de Nemours and Company

Savannah River Site

Aiken, South Carolina 29808

This report was prepared as an account of work sponsored by an agency of the United States Government. Neither the United States Government nor any agency thereof, nor any of their employees, makes any warranty, express or implied, or assumes any legal liability or responsibility for the accuracy, completeness, or usefulness of any information, apparatus, product, or process disclosed, or represents that its use would not infringe privately owned rights. Reference herein to any specific commercial product, process, or service by trade name, trademark, manufacturer, or otherwise does not necessarily constitute or imply its endorsement, recommendation, or favoring by the United States Government or any agency thereof. The views and opinions of authors expressed herein do not necessarily state or reflect those of the United States Government or any agency thereof.

DOE Contract No.

This paper was prepared in connection with work done under the above contract number with the U. S. Department of Energy. By acceptance of this paper, the publisher and/or recipient acknowledges the U. S. Government's right to retain a nonexclusive, royalty-free license in and to any copyright covering this paper, along with the right to reproduce and to authorize others to reproduce all or part of the copyrighted paper. 


\section{DISCLAIMER}

Portions of this document may be illegible in electronic image products. Images are produced from the best available original document. 


\section{INTER-OFFICE MEMORANDUM}

Savannah River Plant

DPSP-88-71-01

FEBRUARY 3, 1988

II TRMMATION ONLY

TO: A. E. HADDEN, 703-M, A-113

RAW MATERIALS ENGINEERING AND TECHNOLOGY DEPARTMENT

FROM: J. A. BURK, 313-M YAS

RAW MATERIALS ENGINEERING AND TECHNOLOGY DEPARTMENT

\section{COMPARISON OF AIR AND WATER QUENCHING OF HDS SLUGS}

This memorandum recommends the use of water quenching, rather than air quenching, for pressed slugs in any future project to substantially update the Building 313-M slug manufacturing facility.

At the outset of the recently cancelled Project S-4092, Inproved Slug Processing Facility (ISPF), 313-M, consensus of the SRP liaison team was to replace the existing water quench facility with air quenching. Principal motivations were to eliminate a liquid waste stream, reduce the quantity of process water used, and attain a more reliable mechanical system. During the ensuing years, unforeseen difficulties with air quenching have been realized. Also, effective methods of reducing and treating the waste streams generated by water quenching have been developed.

Both methods we believe will work. However, the propriety of either method of quenching is a function of the system into which it is being incorporated. Each method carries with it a lot of concealed constraints and carefully designed additional equipment. There is today a concensus that water quenching is preferable. For future reference, some advantages and disadvantages of the two quenching methods are discussed below.

\section{AIR QUENCH ADVANTAGES}

- Slug cooling is accomplished while eliminating a liquid waste stream. No environmental problem is expected.

- Although it was initially believed that better can-to-core bond strengths would result by using air vs a liquid quench, SRL Technical tests have shown that bond strengths by the two methods are the same. [DPST-85-490]

\section{AIR QUENCH DISADVANTAGES}

- Long delay times are required for slug cooling before slugs may be manually handled to perform necessary and mandatory inspections, hammer tests, etc. Unless a rapid quench mechanism is devised, this would cause unacceptable delays in defining quality and making 
necessary adjustments to the press(es) which are currently done on a trial and error/iterative basis. Unadressed, this translates into sizable amounts of non-productive machine time and the possibility of large numbers of poor quality slugs.

- Due to the low melting point of aluminum and the excessive weight of a typical slug assembly, mechanical handling/transport of the unquenched slugs at elevated temperatures without causing surface blemishes is difficult.

- Slugs must be safely stored until they can be cooled. Due to the large number of slugs cooling at any one time, this facility would be a large piece of equiptment. Such storage devices must provide enough clearance/precision to insure against mechanical misalignment which would result in mars to the slug surfaces.

- A hot slug storage facility must be designed to address any housekeeping or maintenance problems which would result from aluminum fragments and the continual buildup of lubricants (Fiske, Grapho, etc.) that would be transported to the facility in a liquid or vapor state by the hot slugs.

- A method of ventilation would be required until the slug heat and lubricant vapors are dissapated. Such a system would necessarily be quite sizable to insure adequate air flow for hundreds of slugs.

- Hot aluminum slugs must be quenched before rib trimming and flash removal. Numbering of slugs on the diametral surface has not been demonstrated in the hot state but has been proven by a dot matrix - solenoid driven pen method on the bottom surface up to $500^{\circ} \mathrm{C}$, which is $100^{\circ} \mathrm{C}$ hotter than the temperature of just pressed slugs. At the higher temperatures however, there was an increasing tendency for aluminum to build up on the pen.

\section{WATER QUENCH ADVANTAGES}

- Water quenching slugs has been proven as an affective method of rapidly cooling a slug so it can be manually handled safely within two minutes after pressing. This allows rapid inspections and slug quality determinations which permit "on the fly" adjustments of pressing variables. In order to insure slug quality, it is necessary to have rapid turnaround of inspection results, otherwise large numbers of poor quality product may result.

- Environmental issues for waste streams generated by water quenching have been addressed and pose no difficulty using the currently operating quench system. Equipment required for processing the water for recycle and recovering spent lubricants for disposal has proven reliable. This system can be (and currently is) designed to collect for disposal any HDS system hydraulic fluid leaks eliminating the need for a separate system.

- Rapid cooling enables a number to be placed on the slug shortly after pressing. This eliminates an unnecessarily large control system to track the slug through the system until cooling to insure the proper number is placed on the correct slug. In general, the earlier the number can be placed on the slug the better.

- Rapid cooling allows for early rib and flash removal. In addition, the early ability to machine the slug bottom is gained. Machining of the slug bottom provides a smooth bottom surface on which to index or rest for subsequent machining steps. It also gives a prepared surface on which to engrave/print a machine readable identification number that can be used for process monitoring and meeting Quality Assurance requirements. 


\section{WATER QUENCH DISADVANTAGES}

- Water quenching requires an oil/water separater/decanter system as well as a filtration system to remove any solids. Along with such a system there are by-products generated which must be disposed of properly. Oil and grease are accumulated in the quench water and are decanted by a system into drums for disposal. Such collected fluids can be properly disposed of by incineration at the local powerhouse. A filter press using a cellulose and diatomaceous earth filter aid mixture is needed to remove any graphite from the recirculating quench water. The resulting dried filter cake mixture and filter paper is disposable at the site sanitary land fill. Such a system is in operation currently in Building $313-\mathrm{M}$ and is very dependable.

- The indexing of parts through liquid has its own particular difficulties from the electrical, mechanical and safety standpoint. Care must be taken to insure against the perculation of boiling water resulting in possible injuries. Additionally, the plant has had many problems resulting from flimsy mechanical design and inaccessible indexing components. The service of this piece of machinery mandates that all the electrical components (i.e. proximity switches, limit switches, photocells, etc.) be carefully selected and located for servicability and endurance in a rugged environment.

- As in the air quench, slugs will be introduced into this facility at about $400^{\circ} \mathrm{C}$ which warrents special protection against mars.

JAB:jab

CC: J. L. Womack, 703-A, A-218

W. P. Mayson, 703-A, A-109

L. C. Brown, 730-M

D. J. Green, $730-M$

C. W. Mettlen, 704-M

J. W. Runnels, 321-M

R. F. Parry, 730-M

R. A. Lee, Jr., 730-M

G. D. Thaxton, 313-M

R. E. Taylor, 313-M

D. K. MoKenzie, 730-M

C. P. Pate, 313-M

D. J. Bills, $730-M$

P. F. Cloessner, 730-M

M. J. Sutton, 320-M

P. K. Gurney, 313-M

B. D. Rykaczewski, 313-M
C. K. Brendell, 730-M

R. A. Hunt, 730-M

J. R. Pelfrey, 313-M

D. R. Leader, 773-A

E. R. Hartman, 773-A

J. A. Quillen, 773-A

P. K. Gurney, 313-M

G. D. Teese, 773-A

R. V. Miller, 773-A

M. J. Schubert, 730-M

R. S. Senkowsky, 313-M

E. E. Smith, 730-M

H. J. Long, 730-M

File 6.3.2.6, 313-M

File $10.2,730-M$

Central Files, 703-A 